\title{
Evaluation of Corporate Bond Market Performance in Bangladesh
}

\author{
Abu Hanifa Md. Noman Bin Alam* \\ Serajul Islam ${ }^{* *}$ \\ Nazneen Jahan Chy ${ }^{* * *}$
}

\begin{abstract}
Bond market plays a vital role in economic development of a country. Bond market provides long term finance to issuers by creating alternative source of finance through stock market, besides providing stable source of income to investors against volatile stock market. However, Bangladesh corporate Bond market is at very initial stage. Hence, it is needed to make an analysis of investors' attitude towards corporate bonds in Bangladesh for determining investors finding on the issue. The study is limited to performance evaluation of three corporate bonds in corporate bond market in Bangladesh and investigate investors attitude towards it. We have collected secondary information from DSE web site and processed through SPSS to make performance analysis and collected primary data from investors of some brokerage houses in Chittagong metro through questionnaire survey for analyzing investors' attitude towards corporate bond market. The study has found that price stability of ACI zero coupon bond is more than IBBL Perpetual Mudaraba Bond and BRAC subordinated convertible bond and it is also found that only 5\% of respondents prefers to invest in corporate bonds due to lack of supply of corporate bond, lack of investors' awareness, inadequate market regulations etc.
\end{abstract}

Key Words: Investor, issuer, corporate bond, corporate bond market.

\footnotetext{
* Lecturer, Dept. of Business Administration, International Islamic University Chittagong.

** Associate Professor, Dept. of Business Administration, International Islamic University Chittagong.

*** Assistant Professor, Dept. of Business Administration, International Islamic University Chittagong
} 


\section{Introduction:}

A well developed financial system mobilizes savings and facilitates investment in an efficient manner for accelerating economic growth $(\mathrm{Mu}, 2007)$. It is considered as a precondition of ecomonic development. Within the financial system, financial market consists of money market, capital market, and derivative market etc. play an important role for the economic development. The debt market being an integral part of financial market plays a complementary role in developing economy through allocation of funds to the different deficit sectors. The debt market consists of money market, mortgage market, bond market and derivative market. Bond market is one of the diversification of a country's financial sector and it also reduces foreign currency risk (Misir, M. Abu, et. al, 2010). The debt market of Bangladesh is very small. Government debt securities such as treasury bills, treasury bonds and National Savings Certificates (NSA) dominate the market, among which NSA account for roughly twothirds. The corporate bond issues had been very occasional and had been stagnant due to a lack of varied corporate debt supply (Jahur, 2009). This is because, in general, companies prefer to rely on banks for funds rather than on the bond market, thereby avoiding the need to comply with disclosure and governance norms. The Milken Institute's Capital Access index (CIA) ranked Bangladesh $75^{\text {th }}$ in bond market development where India stood $35^{\text {th }}$ place in the year 2008 (Milken Institute, CAI Index, 2008).Bangladesh's bond market represents the smallest in South Asia, accounting for only 12 percent of the country's gross domestic product (GDP) (World Bank Report). A corporate bond is a bond that a corporation issues to raise money in order to expand its business (Sullivan, Arthur; Steven M. Sheffrin, 2003). The Bond Market of Bangladesh is at growing stage. One of the main functions of a corporate bond market is to provide long term finance by creating alternative source of finance through capital market. The main purpose of Bond market is to provide stable source of income to the investors against volatile equity market. The Bangladesh capital market is yet to develop required ground to create the environment for a congenial bond market. The high rate of interest in the market and government savings instrument, soft infrastructure for Bond market, unrestricted bank finance etc. all are still congenial for a sound Bond market. In addition the investors are more interested in short term gains instead of waiting for higher returns. The mentioned scenario together with the attitude of the Islamic minded investors against interest income is responsible for non development of Bond market in the country. A 
number of listed companies issued some debentures and listed them with stock exchange but those debentures could not draw the attention of the investors. Some also failed to pay the installments. In recent days IBBL issued MPB and ACI Company issued Zero Coupon Bonds with attractive tax incentives. BRAC bank also issued BRAC Bank 25\% Subordinated Convertible Bonds to raise Tier-II capital to comply with the regulatory requirement of Bangladesh Bank. Credit Rating Agency of Bangladesh (CRAB) Limited has assigned A3 (Single A three) rating to the proposed issuance of BDT 2,000 million $20 \%$ convertible zero coupon bond by Jamuna Bank Limited (hereinafter also referred to as JBL or the Bank). Bangladesh Bank and SEC with support of the Ministry of Finance have been exploring the feasibility and modus operandi to explore the issue for the interest of the capital market. In today's inefficient security market of Bangladesh, researchers and financial analysts put great effort in developing efficient security market as well as corporate bond market in order to make the security market efficient. Security market is of great importance to the academicians and the researchers. It comprises of both share and bond markets. But the majority of the study is being carried out based on share market of Bangladesh. A very few studies have been carried out based on bond market and also on corporate bond market. Basically, this is the main motive of this study to evaluate corporate bond market performance of Bangladesh.

\section{Objectives of the Study:}

The primary objective of the study is to evaluate corporate bond market performance in Bangladesh. To fulfill the primary objective, the following specific objectives are set:

i. To examine the Corporate Bond Market status of Bangladesh

ii. To analyze the Investors' attitude towards Corporate Bonds.

iii. To identify the major problems associated with the Corporate Bond Market of Bangladesh.

iv. To suggest the policy measures for improving the Corporate Bond Market of Bangladesh.

\section{Methodology of the study:}

The researchers have used both primary data and secondary data in this study. The primary data are collected through a structured 
questionnaire survey which conducted among 40 investors in different brokerage houses of Chittagong stock exchange for understanding investors' attitude towards corporate bonds in Bangladesh. Where as, the secondary data sources include the different types of Books, Research Journals, Publications regarding bond \& capital market and the websites of IBBL, ACI Limited, BRAC bank Limited, SEC, CSE and DSE. The data are processed through SPSS and presented through using some statistical tools like descriptive statistics, tables, Pie chart and bar diagram.

\section{About the Issuers:}

\subsection{Islami Bank Bangladesh Limited (IBBL):}

IBBL was established in March 13, 1983 as a public limited company under Companies Act, 1913 (amended in 1994). The bank started its operation on March 30, 1983 under the ambit of Banking Company Ordinance, 1962 (amended in 1991) as the first interest free Shari'ah based Commercial Bank with a mission to establish Islamic Banking through the introduction of welfare oriented banking system. The Bank is enlisted with DSE \& CSE. IBBL has been declared as one of the 20 Blue Chip companies by DSE and as one of the 30 best companies by CSE. The bank provides a wide range of Islamic banking services. The major portion of investment portfolio of IBBL is towards corporate while the rest is towards SME, Specialized Schemes and retail investments. The bank carries out its business activities through 251 branches with the total staff strength of 10068 .

IBBL is holding a diverse shareholding pattern with foreign and domestic sponsor shareholders. IBBL is a first generation private sector bank in the country and is one of the best performing banks of the nation. The management has been taking utmost care maintaining capital adequacy and liquidity management as per requirement of Bangladesh Bank and maintains excellent growth with strategic plan to expand branch network, deposit and investment, develop new products and savings schemes. The bank has been operating profitably since the beginning of its journey keeping the internal capital generation high, following very cautious lending policy to keep the quality of asset strong. 
Details of the Issue:

\begin{tabular}{|c|c|c|c|}
\hline Description & No. of units & Offer in Tk. & Amount Tk. \\
\hline $\begin{array}{c}\text { Pre-IPO } \\
\text { Placement }\end{array}$ & $1,500,000$ & 1000 & $1,500,000,000$ \\
\hline Public Offering & $1,500,000$ & 1000 & $1,500,000,000$ \\
\hline $\begin{array}{c}\text { Total Value of } \\
\text { Bond after IPO }\end{array}$ & $3,000,000$ & 1000 & $3,000,000,000$ \\
\hline
\end{tabular}

Basic Information of the Issue:

\begin{tabular}{|c|c|}
\hline Category & Description \\
\hline Name of the Bank & Islami Bank Bangladesh Limited \\
\hline Size of the issue & $\begin{array}{l}\text { Tk. } 3000 \text { million (Tk. } 1500 \mathrm{~m} \text { in private } \\
\text { placement and Tk. } 1500 \mathrm{~m} \text { in IPO) }\end{array}$ \\
\hline Unit price & Tk. 1000 \\
\hline Market Lot & 5 \\
\hline Term & Perpetual ( No maturity period) \\
\hline Profit Distribution & $\begin{array}{l}\text { i) MPB carries } 1.25 \text { weightage for } \\
\text { distribution of profit } \\
\text { ii) Not less than } 65 \% \text { of the income } \\
\text { generated by deployment of MPB fund and } \\
\text { iii) An additional rate of profit } \\
\text { equivalent to } 10 \% \text { of the rate of dividend } \\
\text { declared by the IBBL every year. No portion of } \\
\text { dividend will be distributed to the MPB holders. }\end{array}$ \\
\hline $\begin{array}{l}\text { Minimum } \\
\text { Subscription }\end{array}$ & Tk. 5000 or Multiple of Tk. 5000 \\
\hline Credit Rating & $\begin{array}{l}\text { MPB has been rated A+ Credit Rating } \\
\text { Information and Services Limited (CRISL) }\end{array}$ \\
\hline Trustee & Investment Corporation of Bangladesh (ICB) \\
\hline $\begin{array}{l}\text { Manager to the } \\
\text { Issue }\end{array}$ & $\begin{array}{l}\text { ICB Capital Management Limited (A subsidiary } \\
\text { company of ICB) }\end{array}$ \\
\hline
\end{tabular}

\section{2 BRAC Bank Limited:}

BRAC Bank Limited is one of the leading private banks in Bangladesh. BRAC Bank has received the commercial banking license from Bangladesh Bank in 2001. It is owned partially by BRAC, the largest non-government organization in the world, International Finance Corporation (IFC), the private sector arm of 
The World Bank Group, and ShoreCap International. Currently, BRAC Bank has 100 Branches, 60 SME Service Centers, 3 SME/Krishi Branches, more than 300 ATMs and 424 SME Unit offices across the country. It has disbursed over BDT10,000 crores of SME loan and has over 500,000 individual customers who access online banking facilities. Its services cut across all strata of clientele be it corporate, retail or SME. BRAC Bank provides all sort of banking service to the mass people of Bangladesh. Among them, BRAC Bank is well known for its SME Banking in Bangladesh.

Details of the Issue:

\begin{tabular}{|l|c|c|c|}
\hline Description & No. of units & Offer in Tk. & Amount Tk. \\
\hline $\begin{array}{l}\text { Pre-IPO } \\
\text { Placement }\end{array}$ & $2,700,000$ & 1000 & $2,700,000,000$ \\
\hline Public Offering & 300,000 & 1000 & $300,000,000$ \\
\hline $\begin{array}{l}\text { Total Value of } \\
\text { Bond after IPO }\end{array}$ & $3,000,000$ & 1000 & $3,000,000,000$ \\
\hline
\end{tabular}

Basic Information of the Issue:

\begin{tabular}{|l|l|}
\hline Category & Description \\
\hline Name of the Bank & BRAC BankLimited \\
\hline Size of the issue & $\begin{array}{l}\text { BDT 3,000,000,000 (Bangladesh Taka Three } \\
\text { Billion) }\end{array}$ \\
\hline Unit price & Tk. 1000 \\
\hline Market Lot & 5 \\
\hline Term & $\begin{array}{l}84 \text { months from the date of issue, bullet } \\
\text { repayment }\end{array}$ \\
\hline Interest Floor & $\begin{array}{l}\text { The interest Margin plus the Reference Rate } \\
\text { will be set at 12.50\% (the Interest Floor) at all } \\
\text { times. }\end{array}$ \\
\hline Trustee & The City Bank Limited \\
\hline Manager to the Issue & IDLC Finance Limited \\
\hline
\end{tabular}

\section{3 Advanced Chemical Industries (ACI) Limited:}

Advanced Chemical Industries (ACI) was established as the subsidiary of Imperial Chemical Industries (ICI) in the then East Pakistan in 1968. After independence the company has been incorporated in Bangladesh on the 24th of January 1973 as ICI Bangladesh Manufacturers Limited and also as Public Limited Company. This 
Company also obtained listing with Dhaka Stock Exchange on 28 December, 1976 and its first trading of shares took place on 9 March, 1994. Later on 5 May, 1992, ICI plc divested $70 \%$ of its shareholding to local management. Subsequently the company was registered in the name of Advanced Chemical Industries Limited. Listing with Chittagong Stock Exchange was made on 22 October 1995. (ACI) Limited is one of the leading conglomerates in Bangladesh, with a multinational heritage. The company has diversified into three major businesses: Pharmaceuticals, Consumer Brands \& Commodity Products and Agribusinesses.

Details of the Issue:

\begin{tabular}{|l|c|c|c|}
\hline Description & No. of units & Offer in Tk. & Amount Tk. \\
\hline $\begin{array}{l}\text { Pre-IPO } \\
\text { Placement }\end{array}$ & 801,510 & 1000 & $801,510,000$ \\
\hline Public Offering & 534,340 & 1000 & $534,340,000$ \\
\hline $\begin{array}{l}\text { Total Value of } \\
\text { Bond after IPO }\end{array}$ & $1,335,850$ & 1000 & $1,335,850,000$ \\
\hline
\end{tabular}

Basic Information of the Issue:

\begin{tabular}{|l|l|}
\hline \multicolumn{1}{|c|}{ Category } & \multicolumn{1}{c|}{ Description } \\
\hline $\begin{array}{l}\text { Name of the } \\
\text { Company }\end{array}$ & ACI Limited \\
\hline Size of the issue & $\begin{array}{l}\text { Tk. 1,335,850,000 (Tk. 801,510,000 in private } \\
\text { placement and Tk. 534,340,000 in IPO) }\end{array}$ \\
\hline Unit price & Tk. 1000 \\
\hline Market Lot & 5 \\
\hline Term & 5 years with yearly redemption \\
\hline Discount rate & 10.50 percent \\
\hline $\begin{array}{l}\text { Minimum } \\
\text { subscription }\end{array}$ & Tk. 3743 \\
\hline Credit Rating & $\begin{array}{l}\text { ACI 20\% Convertible Zero Coupon Bonds has } \\
\text { been rated A+ by Credit Rating Information } \\
\text { and Services Limited (CRISL) }\end{array}$ \\
\hline Trustee & $\begin{array}{l}\text { Industrial and Infrastructure Development } \\
\text { Finance Company Limited (IIDFC) }\end{array}$ \\
\hline Manager to the Issue & Alliance Financial Services Limited \\
\hline
\end{tabular}




\section{Distinguishing Features of different types of Bonds:}

Currently in Bangladesh there are three corporate bonds in Bangladesh. The comparative features of the listed corporate bond are presented below:

\begin{tabular}{|c|c|c|c|}
\hline Features & $\begin{array}{l}\text { Mudarabah } \\
\text { Perpetual } \\
\text { Bond (MPB) }\end{array}$ & $\begin{array}{l}\text { BRAC Bank } \\
25 \% \\
\text { Subordinated } \\
\text { Convertible } \\
\text { Bonds }\end{array}$ & $\begin{array}{l}\text { ACI } 20 \% \\
\text { Convertible } \\
\text { Zero Coupon } \\
\text { Bonds }\end{array}$ \\
\hline Maturity & $\begin{array}{l}\text { It is at perpetual } \\
\text { nature \& will } \\
\text { not be } \\
\text { redeemed. }\end{array}$ & $\begin{array}{l}84 \text { months from } \\
\text { the date of } \\
\text { issue. }\end{array}$ & $\begin{array}{l}5 \text { years with } \\
\text { yearly } \\
\text { redemption. }\end{array}$ \\
\hline $\begin{array}{l}\text { Rate of } \\
\text { profit/interest }\end{array}$ & $\begin{array}{l}\text { Investor is } \\
\text { getting profit by } \\
\text { deployment of } \\
\text { Mudaraba Fund } \\
\text { at the weight } \\
1.25 \text { plus } \\
\text { equivalent to } \\
10 \% \text { of declared } \\
\text { dividend. }\end{array}$ & $\begin{array}{l}\text { The interest } \\
\text { Margin plus the } \\
\text { Reference Rate } \\
\text { will be set at } \\
12.50 \% \text { (the } \\
\text { Interest Floor) } \\
\text { at all times. }\end{array}$ & $\begin{array}{l}\text { The discount } \\
\text { rate is } 10.50 \%\end{array}$ \\
\hline $\begin{array}{l}\text { Conversion } \\
\text { option }\end{array}$ & $\begin{array}{l}\text { No more } \\
\text { conversion ratio }\end{array}$ & $\begin{array}{l}\text { The investor } \\
\text { has the right to } \\
\text { convert } 25 \% \text { of } \\
\text { the face value at } \\
\text { a pre- } \\
\text { determined } \\
\text { Conversion } \\
\text { Strike Price into } \\
\text { the common } \\
\text { shares. }\end{array}$ & $\begin{array}{l}\text { The investor has } \\
\text { the option to } \\
\text { convert } 20 \% \text { of } \\
\text { the bond at face } \\
\text { value in a } \\
\text { predetermined } \\
\text { conversion strike } \\
\text { price. The } \\
\text { investor will } \\
\text { execute the } \\
\text { convertibility } \\
\text { option assuming } \\
\text { that the market } \\
\text { value of ACI } \\
\text { stock is higher } \\
\text { than the } \\
\text { conversion strike } \\
\text { price on the } \\
\text { conversion date. }\end{array}$ \\
\hline
\end{tabular}




\begin{tabular}{|c|c|c|c|}
\hline Purpose & $\begin{array}{l}\text { The main } \\
\text { purpose of the } \\
\text { bond is to raise } \\
\text { fund to meet the } \\
\text { capital } \\
\text { adequacy ratio } \\
\text { of the Bank. } \\
\text { Since the } \\
\text { raising of Tier-1 } \\
\text { Capital has } \\
\text { impact on share } \\
\text { value dilution } \\
\text { and dividend } \\
\text { paying capacity } \\
\text { of the bank, the } \\
\text { IBBL has been } \\
\text { looking for } \\
\text { alternate } \\
\text { sources of Tier- } \\
2 \text { Capital as a } \\
\text { subordinated } \\
\text { investment } \\
\text { instrument and } \\
\text { identified the } \\
\text { issuance of } \\
\text { Mudaraba } \\
\text { Perpetual Bond } \\
\text { to resolve the } \\
\text { issue of capital } \\
\text { adequacy. }\end{array}$ & $\begin{array}{l}\text { The main } \\
\text { purpose of the } \\
\text { bond is to raise } \\
\text { Tier } 2 \text { capital } \\
\text { (subject to } \\
\text { regulatory } \\
\text { approval) and } \\
\text { undertake } \\
\text { normal } \\
\text { commercial } \\
\text { activities with } \\
\text { the proceeds as } \\
\text { permitted by the } \\
\text { Bangladesh } \\
\text { Bank. }\end{array}$ & $\begin{array}{l}\text { As a part of } \\
\text { ACI's vision to } \\
\text { look for } \\
\text { alternative } \\
\text { funding } \\
\text { arrangement and } \\
\text { be pioneer in } \\
\text { undertaking new } \\
\text { product in the } \\
\text { capital market, } \\
\text { ACI } \\
\text { Management } \\
\text { envisage that } \\
\text { raising of money } \\
\text { through Zero } \\
\text { Coupon Bonds } \\
\text { would be an } \\
\text { alternative } \\
\text { option for the } \\
\text { company }\end{array}$ \\
\hline Investors & $\begin{array}{l}100 \% \text { issue is } \\
\text { offered to } \\
\text { public through } \\
\text { IPO }\end{array}$ & $\begin{array}{l}90 \% \text { of the total } \\
\text { issue size is } \\
\text { offered to } \\
\text { institutional } \\
\text { investors } \\
\text { including } \\
\text { onshore and } \\
\text { offshore } \\
\text { investors and } \\
\text { the remaining } \\
10 \% \text { is offered }\end{array}$ & $\begin{array}{l}53.85 \% \text { of the } \\
\text { total issue size is } \\
\text { offered to } \\
\text { institutional } \\
\text { investors and the } \\
\text { remaining } \\
46.15 \% \text { is } \\
\text { offered to public } \\
\text { through IPO }\end{array}$ \\
\hline
\end{tabular}




\begin{tabular}{|l|l|l|l|}
\hline & & $\begin{array}{l}\text { to public } \\
\text { through IPO }\end{array}$ & \\
\hline & & $\begin{array}{l}\text { The conversion } \\
\text { date is the same } \\
\text { date will be } 5^{\text {th }}\end{array}$ & $\begin{array}{l}\text { Conversion date } \\
\text { will be same as } \\
\text { the Principal }\end{array}$ \\
$6^{\text {th } \& 7^{\text {th }}}$ & $\begin{array}{l}\text { Conversion } \\
\text { anniversary of } \\
\text { date }\end{array}$ & Nond issuance \\
date & $\begin{array}{l}\text { Payment Date at } \\
\text { the end of each } \\
\text { maturity. }\end{array}$ \\
& & & \\
& &
\end{tabular}

\section{Performance of Bonds in Terms of Price:}

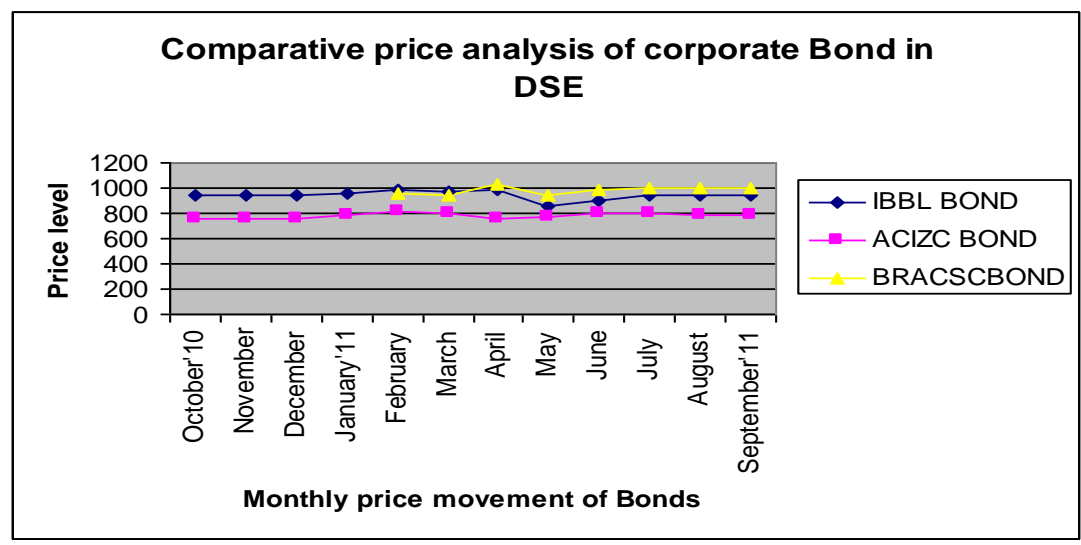

Figure: 1-Monthly price movement of Bonds

Source: DSE web site

http://www.dsebd.org/displayCompany.php?name=BRACSCBOND)

It is found from the above graph that the average monthly price trend line of ACI $20 \%$ covertible zero coupon bond is fairly consistant and upward sloping in comparison with to that of IBBL perpetual mudaraba bond and BRAC bank $25 \%$ subordinated convertible bond.

\begin{tabular}{|c|c|c|c|c|c|c|}
\hline \multicolumn{7}{|c|}{ Descriptive statistics } \\
\hline & $\mathrm{N}$ & Range & Maximum & Minimum & Mean & St.deviation \\
\hline IBBL & 12 & 128.00 & 862.00 & 990.00 & 942.34 & 34.72 \\
\hline BRAC & 8 & 87.00 & 945.00 & 1032.00 & 984.67 & 29.99 \\
\hline ACI & 12 & 54.00 & 754.00 & 808.00 & 783.73 & 19.89 \\
\hline
\end{tabular}


During the period of October 2010 to September 2011, it is found that the price fluctuation of IBBL perpetual mudaraba bond is higher and it is lower in ACI 20\% convertible zero coupon bond in Dhaka stock exchange. It is assumed that investors' attitude and confidence are higher in ACI $20 \%$ convertible bond than those of the bonds in the market.

\begin{tabular}{|l|l|}
\hline correlation & $\begin{array}{l}\text { pearson correlation } \\
\text { coefficient }(\mathrm{r})\end{array}$ \\
$\mathrm{N}=12$ & 0.135 \\
\hline Between IBBL and ACI bond & -0.456 \\
\hline Between ACI and BRAC bond & 0.272 \\
\hline Between IBBL and BRAC bond & \\
\hline
\end{tabular}

Its found from the above pearson correlation value which is calculated using SPSS that Market price of IBBL perpetual mudaraba bond is positively related with the prices of ACI $20 \%$ convertible zero coupon bond and BRAC bank 25\% convertible subordinated bond. But pearson's correlation value between ACI $20 \%$ convertible zero coupon bond and BRAC bank $25 \%$ convertible subordinated bond indicates that price movement between the bonds is negative that is, when one gains another one losses. It seems that investors invest between these two bonds alternatively.

\section{Analysis of Investors' attitude toward corporate bonds in Bangladesh:}

A questionnaire survey was conducted among 40 investors in different brokerage houses of Chittagong stock exchange for understanding investors' attitude towards corporate bonds in Bangladesh. Out of the total respondents $65 \%$ are service holders; $76 \%$ of them are within the age limit of $26-35$ years; $65.79 \%$ have the graduation and $21.05 \%$ have post graduation; $78.95 \%$ of the respondents have knowledge on stock market, $52.63 \%$ depends on friends and families and $47.37 \%$ have own financing for investment and none of them depends on bank borrowing or borrowing from stock broker; $60.53 \%$ of the respondents have the preference for capital gain and only $39.47 \%$ are interested for current income from investment; $52.64 \%$ of the investors adopt technical analysis and $23.68 \%$ makes fundamental analysis and $23.68 \%$ depend on others' information for making investment decision. Risk taking attitude of the most of the respondents is little or moderate; a few of them have aggressiveness towards risk. 
The study reveals that investors' best choice is common stock of the listed companies and one of the worst choices is corporate bond as investment alternative.

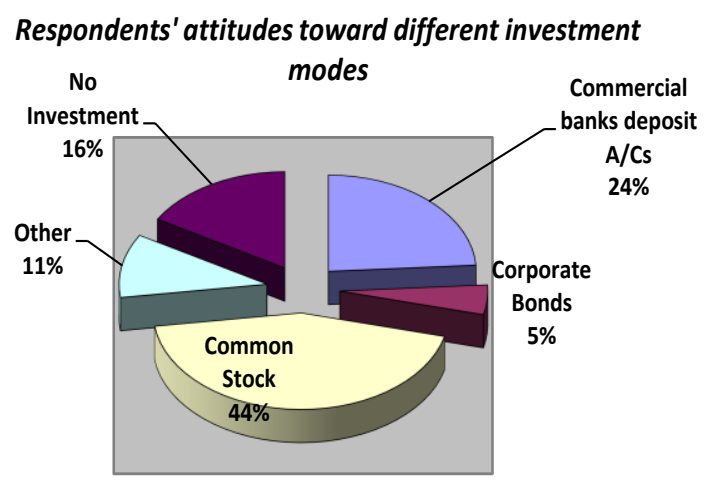

Figure: 2-Respondents' attitude toward different investment modes.

Source: Field survey

$44 \%$ of the respondents are interested to invest in common stock of listed companies and $24 \%$ of them are interested in commercial banks' deposit $\mathrm{A} / \mathrm{Cs}$ and only $5 \%$ of them are interested for corporate bond investment.

The study also shows that most of the respondents believe that the corporate bond market in Bangladesh is not efficient. 
Do you think thot our bond market is efficient?

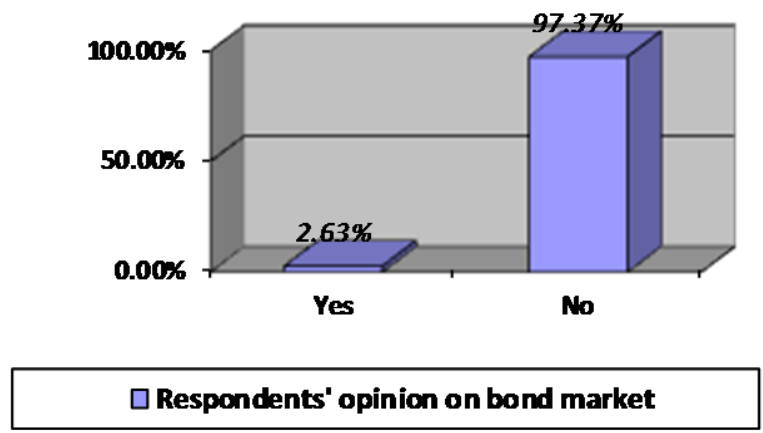

Figure: 3- Efficiency of Corporate Bond market Source: Field survey

The above figure shows that $97.37 \%$ consider that corporate bond market is inefficient and only $2.63 \%$ judge that it is efficient.

The key motivational factor is fixed periodic income for corporate bond investment.

From the following factors which one(s) motivates you for bond investment?

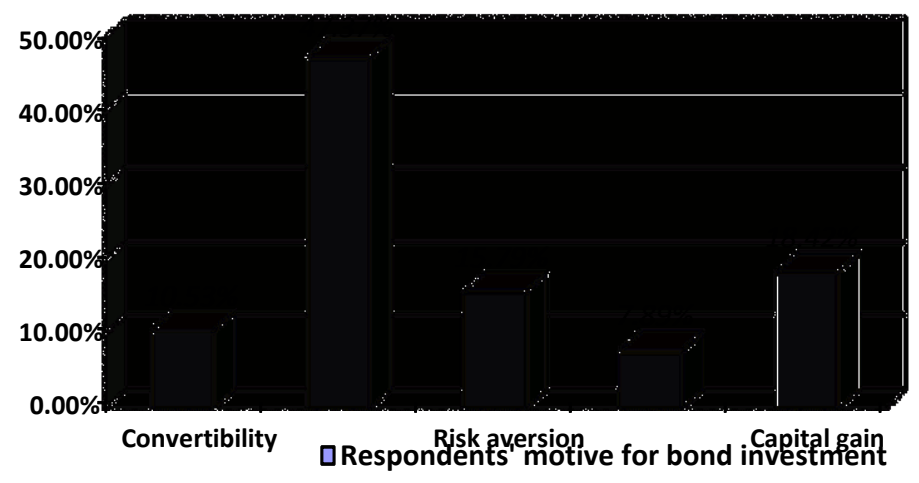

Figure: 4-Respondents' motive for bond investment

Source: Field survey 
The figure shows that $47.37 \%$ of the corporate bond investors makes bond investment for fixed periodic income, $15.79 \%$ of them invest in the bond as it involves less risk, $18.42 \%$ of them has capital gain preference, $10.53 \%$ likes it for convertible feature and only $7.89 \%$ choices it for having tax advantage.

\section{Problems of Bangladesh Corporate Bond Market:}

The corporate Bond Market in our country has been growing on different fronts year by year; but the growth in different parameters is still at low level as compared to emerging stock market in the world in general, and in Asia in particular. This stage of development can be attributed to different issues. The study has identified some important issues to the development of the market by conducting interview of 40 personnel associated with corporate bond market.

Table-: Statement of Problems Associated with corporate bond market

\begin{tabular}{|l|c|c|}
\hline \multicolumn{1}{|c|}{ Problems } & $\begin{array}{c}\text { No of } \\
\text { Respondents }\end{array}$ & $\begin{array}{c}\text { Percentage of } \\
\text { Respondents }\end{array}$ \\
\hline 1. $\begin{array}{l}\text { Inadequate market } \\
\text { regulation }\end{array}$ & 27 & $67.5 \%$ \\
2. $\begin{array}{l}\text { Lack of actions } \\
\text { against market } \\
\text { manipulator. }\end{array}$ & 23 & $57.5 \%$ \\
3. $\begin{array}{l}\text { Inadequate disclosure } \\
\text { of information } \\
\text { according to the } \\
\text { globally accepted } \\
\text { accounting standards, } \\
\text { say IASs, IFRS } \\
\text { information }\end{array}$ & 22 & $55 \%$ \\
4. $\begin{array}{l}\text { Lack of supply of } \\
\text { bond in the market }\end{array}$ & 18 & $45 \%$ \\
5. $\begin{array}{l}\text { Lack of awareness of } \\
\text { investors. }\end{array}$ & 19 & $47.5 \%$ \\
6. $\begin{array}{l}\text { Volatile political } \\
\text { situation }\end{array}$ & 04 & $10 \%$ \\
7. $\begin{array}{l}\text { High interest rate in } \\
\text { the money market }\end{array}$ & 06 & $15 \%$ \\
\hline
\end{tabular}




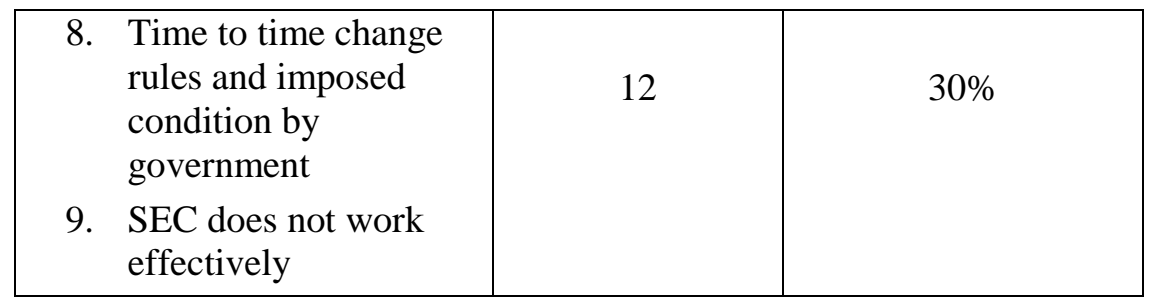

Source: Field survey

\section{Recommendations for the Development of Corporate Bond Market}

The analysis shows that the corporate bond market in Bangladesh is at very initial stage which is launched in 2007 with floating IBBL perpetual mudaraba bond and only three corporate bonds are listed in the market where only $5 \%$ of the investors are involved in it. As Bond market provides long term finance to issuers by creating alternative source of finance through stock market and it's at the early state, the growth potentiality of the market is very high. The authors believe that this is the right time to implement some policy measures for exploiting the growth potentialities of the market. Following policies have been put forwarded for the development of corporate bond market in Bangladesh:

i. Securities and Exchange Commission (SEC) should deregulate the existing laws and promulgate news laws for creating congenial regulatory environment for the development of bond market in the country.

ii. SEC should take initiative to identify the market manipulators and take actions for punishing them to bring confidence of general investors on the market.

iii. Issuing company should disclose information publicly so that investors can be aware of issuing companies' borrowing capacity and financial strength.

iv. There is no alternative to develop the bond market without increasing supply of bonds in the market. Government should reduce granting financial assistance to state owned corporations by encouraging them to raise fund from the market by issuing corporate bonds. 
v. SEC should undertake both education and training programs for the market participants for creating awareness about the benefits of corporate bond investment among the market participants.

vi. Political stability is the precondition for sustainable development of the market; therefore, government should try to keep political situation stable.

vii. Establishment of Dhaka Inter-bank Offered Rate is one step ahead for the developing of bond market. It has to give a fair opportunity for establishment of long term yield curve.

viii. The Government may offer defined fiscal benefits in corporate bond investment for the development of corporate bond market in Bangladesh.

ix. The government is also required to address high issuing costs, and create an environment conducive to the development of bonds by lowering the interest on national savings certificates.

x. Freedom of Credit Rating Agencies should be enhanced so that they can work freely and independently.

xi. Central Bank can allow commercial banks to invest in investment grade bonds and debentures to form parts of their SLR.

\section{Conclusion and Future Research:}

The aim of our study was to determine the market performance appraisal of three listed corporate bonds in Bangladesh corporate bond market and investors' attitude analysis towards it. It is important to note that one year's monthly price information are collected from DSE web site for performance appraisal and primary data are collected from only 40 investors of some brokerage houses at only in Chittagong Metropolitan area for analyzing investors' attitude towards corporate bond market in Bangladesh. Therefore, the study result refers only to the sample information collected. The results obtained through SPSS found that standard deviation of monthly price of ACI is 19.99 which is lower than 34.72 of IBBL MPB and 29.99 of BRAC SCB. It is also found that corporate bond market of Bangladesh is not an efficient one and the investors are lack of concern on it. The Securities and Exchange Commission (SEC) should take necessary steps to make it efficient because corporate bond market plays an important role for the economic development of the country. The future research can be 
carried out by using more secondary information regarding price performance and collecting primary data through an extensive questionnaire survey. The similar study can be done also on investors' attitude towards government bonds in Bangladesh.

\section{References:}

1. Akter, Nazma and Mohsin M., (2010), Heterogeneous investors Base in Government Bond Market: A Critical Review of Some Selected south Asian countries, Thoughts on Economics, Vol. 20. No. 02, p-68.

2. Islam, ABM. Mahbubul (2005), Islamic Constitution: Quranic and Sunnatic Perspectives, Professors Publication, Dhaka, p-331.

3. Jahur, M. Saleh (2009), Development of Bond Market in Bangladesh: Issues, Status, and Policies, CSE Portfolio, July-September, 2009, p-49.

4. Jahur M. S. and Quadir N. (2010), Development of Bond Market in Bangladesh: Issues, Status, and Policies, Management Research and Practice, Vol. 2, Issue 3, p:312.

5. Misir, M. Abu, Mohsin M., and Kamal A., (2010), Contemporary Issues in Bond Market Development in Bangladesh: Experience and Evidence from Asian Countries, The Bangladesh Accountant, January-March 2010, p-27.

6. Mu, Yibin (2007), South Asia Bond Markets and Bangladesh, World Bank Dhaka

7. Sharif, M. Raihan (1996), Guidelines to Islamic Economics: Nature, Concepts and Principles, Bangladesh Institute of Islamic Thought (BIIT), p-166.

8. Sullivan, Arthur; Steven M. Sheffrin (2003). Economics: Principles in action. Upper Saddle River, New Jersey 07458: Pearson Prentice Hall. pp. 281. ISBN 0-13-063085-3.

9. Usmani, M. Taqi,(1998), Sukuk and their Contemporary Applications, AAOIFI Shariah Council, P-2.

10. Vuong, Quan Hoang; Tran, Tri Dung (2010). "Vietnam's Corporate Bond Market, 1990-2010: Some Reflections". The Journal of Economic Policy and Research (Institute of Public Enterprises) 6 (1): 1-47. 
IIUC Studies, Vol. 10 \& 11

\section{Websites:}

i. http://www.islamibankbd.com/home.php

ii. http://bd-ipo.blogspot.com/2010/01/aci-limited-aci-20-convertiblezero.html

iii. http://www.dsebd.org/forthcoming/Brac Bonds.pdf

iv. http://www.pearsonschool.com/index.cfm?locator=PSZ3R9\&PMDbSiteI $\mathrm{d}=2781 \&$ PMDbSolutionId=6724\&PMDbCategoryId=\&PMDbProgramI $\underline{\mathrm{d}=12881 \& \text { level }=4}$

v. http://www.vietnamica.net/op/wpcontent/uploads/2010/11/VuongTran.JEPR_Vol6_No1_.2011.pdf 